- FINANSE I PRAWO FINANSO WE.

- Journal of Finance and Financial Law

Grudzień/December 2019 • vol. 4(24): 99-123

http://dx.doi.org/10.18778/2391-6478.4.24.07

\title{
USŁUGI FINANSOWE A TECHNOLOGIA BLOCKCHAIN - AKTUALNE PROBLEMY ORAZ WYZWANIA PODATKOWE
}

\author{
Maria Supera-Markowska \\ Katedra Prawa Finansowego, \\ Wydział Prawa i Administracji, Uniwersytet Warszawski
}

\begin{abstract}
Streszczenie
Usługi finansowe wobec możliwości wykorzystania do płatności walut wirtualnych (przede wszystkim bitcoina), opartych na technologii blockchain, nabierają nowego wymiaru. Dokonywanie płatności bezpośrednich z użyciem kryptowalut kreuje zagadnienia istotne podatkowo, zarówno w zakresie samego pozyskiwania, jak i obrotu walutami wirtualnymi, w tym w szczególności wykorzystywania ich do realizacji funkcji płatniczej, ale także traktowania jako inwestycji lub przedmiotu działalności handlowej. Kwestie z tym związane generują liczne wyzwania podatkowe, zarówno w systemie podatków dochodowych, jak i podatków obrotowych oraz majątkowych. Tym wyzwaniom w zakresie podatkowych konsekwencji stosowania w systemie usług finansowych technologii blockchain dla płatności z użyciem kryptowalut poświęcono niniejszy artykuł.
\end{abstract}

Słowa kluczowe: usługi finansowe, blockchain, waluty wirtualne, kryptowaluty, podatki.

JEL Class: K34. 


\section{WPROWADZENIE}

Usługę finansową można zdefiniować jako ustugę świadczona przez podmiot działajacy w sektorze ustug finansowym (pośrednika finansowego), która wiąze się $z$ inwestowaniem bądź pozyskiwaniem środków pieniężnych, a także zzapewnieniem odpowiedniego przeplywu środków pieniężnych pomiędzy uczestnikami rynku [Iwanicz-Drozdowska i in. 2009: 10]. W polskim prawie usługi finansowe są wymienione w art. 4 ust. 2 ustawy o prawach konsumenta [Ustawa z 30 maja 2014 r..., tekst jedn., Dz.U. 2019, poz. 134 ze zm.], zgodnie z którym usługami finansowymi są w szczególności czynności bankowe ${ }^{1}$ oraz usługi płatnicze. Do czynności bankowych należą czynności zastrzeżone wyłącznie dla banków (tzw. czynności bankowe sensu stricto) [Ofiarski 2017: 177 -178], w tym m.in. przyjmowanie wkładów pieniężnych płatnych na żądanie lub $z$ nadejściem oznaczonego terminu oraz prowadzenie rachunków tych wkładów, prowadzenie innych rachunków bankowych, udzielanie kredytów [art. 5 ust. 1 Ustawy z 29 sierpnia 1997 r..., tekst jedn., Dz.U. 2019, poz. 2357 ze zm.), dalej: pr. bank] oraz czynności dozwolone także niektórym podmiotom niebankowym (tzw. czynności bankowe sensu largo) [Ofiarski 2017: 177-179], w tym m.in.: udzielanie pożyczek pieniężnych, świadczenie usług płatniczych czy pośrednictwo w dokonywaniu przekazów pieniężnych oraz rozliczeń w obrocie dewizowym [art. 5 ust. 2 pr. bank].

Na podstawie tych przepisów można wskazać, iż usługi finansowe, zdefiniowane w art. 2 pkt 12 dyrektywy w sprawie praw konsumentów [Dyrektywa Parlamentu Europejskiego i Rady 2011/83/UE z 25 października 2011 r..., Dz.Urz. UE L 304 z 22 listopada 2011 r.: 64-88] jako: każde usługi o charakterze bankowym, kredytowym, ubezpieczeniowym, emerytalnym, inwestycyjnym lub płatniczym, obejmują m. in. świadczenie usług płatniczych.

W przepisach ustawy o usługach płatniczych [Ustawa z 19 sierpnia 2011 r..., tekst jedn., Dz.U. 2019, poz. 659 ze zm., dalej: u.usł.pł.] znajduje się zamknięty katalog określonych rodzajów działalności, którą należy traktować jako usługi płatnicze (w tym m.in.: wykonywanie transakcji płatniczych, w tym transfer środków pieniężnych na rachunek płatniczy u dostawcy użytkownika lub u innego dostawcy [art. 3 ust. 1 u.usł.pł.]). Działalność w zakresie usług płatniczych, w ramach której dostawca usługi wchodzi w posiadanie środków pieniężnych, będących przedmiotem transakcji płatniczej, podlega przepisom u.usł.pł., o ile nie zachodzą, określone w art. 6 u.usł.pł. przesłanki wyłączające stosowanie przepisów tej ustawy [Zalcewicz i Bajor 2016: 34-35]. Tak rozumiane usługi płatnicze mogą być wykonywane przez dostawców usług płatni-

${ }^{1}$ Należy mieć przy tym na względzie istotne różnice terminologiczne w nauce, głównie ekonomii, gdyż zamiast pojęcia czynności bankowe autorzy posługują się pojęciami: operacje bankowe, usługi bankowe czy usługi finansowe [Ofiarski 2017: 175]. 
czych, którymi - oprócz banków - są także m.in. instytucje płatnicze, instytucje pieniądza elektronicznego, biura usług płatniczych [art. 4 ust. 1 u.usł.pł.], czyli różnego rodzaju pośrednicy finansowi, którzy mieliby zostać wyeliminowani w myśl koncepcji płatności bezpośrednich z zastosowaniem sieci $\mathrm{P}^{2} \mathrm{P}^{2}$.

Koncepcja ta została przedstawiona w 2008 r. [Nakamoto, Bitcoin: A Peerto-Peer Electronic Cash System, 2008: 1] i opiera się na idei wprowadzenia na wzór obecnie funkcjonującej gotówki - jej elektronicznej wersji (electronic cash) umożliwiającej dzięki zastosowaniu technologii blockchain dokonywanie płatności bez pośredników finansowych.

Blockchain można zdefiniować jako rozproszona bazę danych, która zawiera stale rosnaca ilość informacji (rekordów) pogrupowanych $w$ bloki i powiazanych ze soba w taki sposób, że każdy nastepny blok zawiera oznaczenie czasu (timestamp), kiedy zostat stworzony oraz link do poprzedniego bloku, będacy zaszyfrowanym ,streszczeniem” (hash) jego zawartości [Piech (red.) 2016: 5].

Technologia ta została po raz pierwszy użyta w $2009 \mathrm{r}^{3}{ }^{3}$ w kryptowalucie bitcoin [Piech (red.) 2016: 5-6], stąd też kojarzona jest najczęściej właśnie $\mathrm{z}$ walutami wirtualnymi, podczas gdy jej zastosowanie może być znacznie szersze ${ }^{4}$.

Bitcoina można zdefiniować, po pierwsze jako walutę wirtualną (cyfrową), a po drugie jako zdecentralizowany system płatności [Barta i Murphy 2018: 21].

Niniejszy artykuł ma na celu przedstawienie podatkowych konsekwencji związanych $\mathrm{z}$ zastosowaniem $\mathrm{w}$ systemie usług finansowych walut wirtualnych (kryptowalut), możliwym dzięki technologii blockchain, oraz dokonanie systemowej oceny obowiązujących w tym zakresie regulacji prawno-podatkowych. Analiza zostanie dokonana na gruncie przepisów prawa podatkowego dotyczących podatków dochodowych, obrotowych i majątkowych, z uwzględnieniem ich ewolucji w ostatnich latach (w tym zwłaszcza zmian obowiązujących od 2019 r.), interpretacji przepisów prawa podatkowego, dorobku orzecznictwa sądowego oraz literatury krajowej i zagranicznej. Wynikające z analizy ustalenia co do tego, czy ustawodawstwo podatkowe uwzględnia w wystarczającym stopniu specyfikę kryptowalut oraz czy ich podatkowe ujęcie w systemie prawa podatkowego spełnia warunki spójności, neutralności i pewności, mają służyć sformułowaniu ewentualnych postulatów de lege lata lub de lege ferenda.

${ }^{2}$ Sieć P2P (ang. peer-to-peer) tworzona jest przez system klientów (programów zainstalowanych na poszczególnych komputerach), które komunikują się ze sobą jako równorzędne węzły w sieci [szerzej zob. Homa 2015: 29 i n.].

3 W styczniu 2009 r. wygenerowano inicjalny blok bitcoina - „blok Genesis” [Klinger i Szczepański 2017: 12-13].

${ }^{4} \mathrm{Na}$ temat znaczenia technologii blockchain, nie tylko w zakresie kryptowalut [zob. Boucher i in. 2017; European Comission..., 2019; Klinger i Szczepański 2017; Kopańko i Kozłowski 2015: 115 i n.]. 


\section{BLOCKCHAIN A PŁATNOŚCI BEZ POŚREDNIKÓW FINANSOWYCH}

Blockchain wiąże się z koncepcją płatności i przepływów funduszy z pominięciem pośredników finansowych (płatności P2P) [Nakamoto 2008: 1 i n.] czy szerzej założeniem powstania ,pieniądza”, a właściwie całego systemu walutowego $\mathrm{w}$ obrocie gospodarczym $\mathrm{z}$ funkcją płatności $\mathrm{z}$ pominięciem banków $i$ innych instytucji finansowych, działającego w przestrzeni cyfrowej [Szostek 2018: 90]. W tym kontekście warto wskazać, iż technologia blockchain (oraz technologia DLT ${ }^{5}$ ) są narzędziami służącymi realizacji koncepcji nowego ładu w cyberprzestrzeni bez udziału dotychczasowych instytucji i organów, opierającymi się na w pełni autonomicznych i demokratycznych działaniach, w których nadzór zostaje przekazany społeczności internautów w miejsce instytucji działających na podstawie reguł prawa krajowego [Szostek 2018: 19].

Można zauważyć, iż spadające znaczenie pośredników ${ }^{6}$ to jeden $\mathrm{z}$ mocno zaznaczających się trendów gospodarki cyfrowej; rezygnacja $\mathrm{z}$ pośredników albo przynajmniej minimalizacja ich roli jest podstawowym celem optymalizacji procesów biznesowych [Szostek 2018: 15]. Idea rezygnacji z pośredników finansowych $\mathrm{w}$ płatnościach stała u podstaw koncepcji kryptowalut, jakkolwiek w praktyce $\mathrm{w}$ miejsce dotychczasowych pośredników (przede wszystkim banków) pojawili się nowi ${ }^{7}$, w tym $\mathrm{w}$ szczególności giełdy kryptowalut ${ }^{8}$ (jakkolwiek można się spodziewać, iż wraz z coraz powszechniejszą akceptacją kryptowalut zapotrzebowanie na usługi giełd będzie maleć) [Barta i Murphy 2018: 79]). Niemniej jednak można stwierdzić, iż zastosowanie technologii blockchain $\mathrm{w}$ płatnościach $\mathrm{z}$ użyciem walut wirtualnych służy pominięciu pośrednictwa banków przy przepływach funduszy.

Kwestiom konsekwencji pominięcia pośrednictwa bankowego przy przepływach funduszy poświęcono m.in. rezolucję Parlamentu Europejskiego w sprawie technologii rozproszonego rejestru i łańcucha bloków: budowanie zaufania dla przepływów funduszy $\mathrm{z}$ pominięciem pośrednictwa bankowego [Rezolucja Parlamentu Europejskiego z 3 października 2018 r..., 2017/2772(RSP)], która uwzględnia m.in. rezolucję Parlamentu w sprawie wirtualnych walut [Rezolucja Parlamentu Europejskiego z 26 maja 2016 r..., 2016/2007(INI)] oraz rezolucję Parlamentu w sprawie FinTech [Rezolucja Par-

${ }^{5}$ Distributed ledger technology, czyli technologia rozproszonego rejestru. Szerzej na ten temat [np. Distributed Ledger Technology...].

${ }^{6}$ oraz platformyzacja czynności.

${ }^{7}$ Rolą pośredników jest zapewnienie mechanizmów konwersji kryptowalut na waluty tradycyjne, dzięki czemu klienci mogą ,wydawać” kryptowaluty, a sprzedawcy otrzymywać zapłatę w walucie tradycyjnej [Barta i Murphy 2018: 71-72].

${ }^{8}$ Giełdy są instytucjami pozwalającymi wymienić kryptowalutę na waluty fiducjarną [Barta i Murphy 2018: 69]. Szerzej na temat giełd kryptowalut zob. np. Homa [2015: 89-101]. 
lamentu Europejskiego 17 maja 2017 r..., 2016/2243(INI)]. Na forum unijnym kwestie użycia kryptowaluty oraz związanych z tym zarówno potencjalnych zagrożeń, jak i pozytywnych efektów, analizował też Europejski Bank Centralny, m.in. w swoim raporcie z 2015 r. [European Central Bank, 2015]. W dokumentach krajowych kwestie zastosowania blockchain i kryptowalut uwzględniono w szczególności w programie Od papierowej do cyfrowej Polski [www6], w ramach którego przewidziano strumień Blockchain/DLT $i$ Waluty Cyfrowe.

\section{KRYPTOWALUTY - DEFINICJE I STATUS PRAWNY}

Na wstępie konieczne jest ustalenie zakresu samego pojęcia i statusu prawnego kryptowalut. Wśród państw z całego świata ${ }^{9}$ występują takie, w których kryptowaluty traktuje się tak, jak waluty FIAT (Luksemburg [www2]), uznaje się je za prywatną walutę (Niemcy) [Homa 2015: 135] albo takie, w których kryptowaluta jest nielegalna (Ekwador, w którym jednakże po zakazaniu obrotu kryptowalutami w 2014 r., już w następnym roku wprowadzano walutę cyfrową: Dinero Electrónico, za którą odpowiada centralny bank Ekwadoru, a jej kurs jest ściśle powiązany $z$ kursem amerykańskiego dolara ${ }^{10}$, będącego oficjalną walutą obowiązującą w tym kraju) [www5].

W prawie unijnym w 2018 r. [Dyrektywą Parlamentu Europejskiego i Rady (UE) 2018/843 z 30 maja 2018 r..., Dz. Urz. UE L 156 z 19 czerwca 2018 r.: 43-74] wprowadzono następującą definicję walut wirtualnych: cyfrowe wyznaczniki wartości, które nie sq emitowane ani gwarantowane przez bank centralny lub organ publiczny, nie musza być powiazane z waluta prawnie obowiqzująca i nie posiadaja prawnego statusu waluty lub pieniadza, lecz które sa akceptowane przez osoby fizyczne lub prawne jako środek wymiany i moga być przekazywane, przechowywane lub sprzedawane droga elektroniczna [art. 3 pkt 18 Dyrektywy Parlamentu Europejskiego i Rady (UE) 2015/849 z 20 maja 2015 r..., Dz.Urz. UE L 141 z 20 maja 2015 r.: 73-117].

W polskim porządku prawnym definicja kryptowaluty, a właściwe waluty wirtualnej $^{11}$, znajduje się w art. 2 ust. 2 pkt 26 ustawy o przeciwdziałaniu praniu

${ }^{9}$ Przegląd regulacji (lub braku regulacji) dotyczących bitcoina w różnych krajach zawarty jest w: The Law Library of Congress, 2014.

${ }^{10}$ Zwrócić należy uwagę, iż to powiązanie oraz zaangażowanie baku centralnego powodują, iż Dinero Electrónico nie można uznać za kryptowalutę, charakteryzowaną m.in. właśnie przez brak centralnego emitenta i organu nadzoru.

${ }^{11}$ Jak wskazuje się w literaturze [Stolarski 2018: 28 i przywołana tam literatura], do czasu pojawienia się pierwszych legalnych definicji walut wirtualnych, zarówno w praktyce, jak i literaturze, termin waluta wirtualna często używany był zamiennie z pojęciami: kryptowaluta, cyberwaluta czy waluta internetowa, ale obecnie termin ten należy uznać za pewnego rodzaju metapojęcie, 
pieniędzy oraz finansowaniu terroryzmu [Ustawa z 1 marca 2018 r..., tekst jedn., Dz.U. 2019, poz. 1115 ze zm., dalej: u.p.p.p.f.t.]. Wynika z niej, iż kryptowaluty nie są pieniądzem, tj. nie są prawnym środkiem płatniczym, ani pieniądzem elektronicznym ${ }^{12}$ czy instrumentem finansowym; nie podlegają zatem przepisom u.usł.pł. ${ }^{13}$, ani ustawy o obrocie instrumentami finansowymi [Ustawa z 29 lipca 2005 r..., tekst jedn., Dz.U. 2018, poz. 2286 ze zm., dalej: u.o.i.f.]. Jednocześnie jednak ani posiadanie, ani obrót kryptowalutami w Polsce nie narusza przepisów prawa, a kryptowalutą można ,płacić” za realne transakcje (oczywiście pod warunkiem, iż druga strona zaakceptuje taką formę ,zapłaty”).

Dla celów podatkowych definicję kryptowaluty (od 2019 r. ${ }^{14}$ ) znaleźć można w obydwu ustawach o podatkach dochodowych [art. 5a pkt 33a Ustawy z 26 lipca 1991 r..., (tekst jedn., Dz.U. 2019, poz. 1387 ze zm., dalej: u.p.d.o.f.) oraz art. 4a pkt 22a u.p.d.o.p. Ustawy z 15 lutego 1992 r..., (tekst jedn., Dz.U. 2019, poz. 865 ze zm.)], które odwołują się wprost do definicji zawartej w u.p.p.p.f.t.. Definicji kryptowaluty nie ma natomiast w ustawie o podatku od towarów i usług [Ustawa z 11 marca 2004 r..., tekst jedn., Dz.U. 2018, poz. 2174 ze zm., dalej: u.p.t.u.], ani w ustawie o podatku od czynności cywilnoprawnych [Ustawa z 9 września 2000 r..., tekst jedn., Dz.U. 2019, poz. 1519 ze zm., dalej: u.p.c.c.] oraz ustawie o podatku od spadków i darowizn [Ustawa z 28 lipca 1983 r..., tekst jedn., Dz.U. 2019, poz. 1813, dalej: u.p.s.d.]. W związku z tym, w zakresie nieuregulowanym wprost w prawie podatkowym, zastosowanie znajduje definicja, a właściwe klasyfikacja, wypracowana

w szczególności w stosunku do terminów kryptowaluta i cyberwaluta, obejmujące zarówno kryptowaluty, jak i inne środki rozliczeń za dobra i usługi, jak mile lotnicze, kupony internetowe oraz mobilne czy nawet nieformalne dokumenty potwierdzające istnienie zobowiązań. W niniejszym tekście pojęcia te (waluty wirtualne i kryptowaluty) będą mimo to stosowane zamiennie, przy czym należy im nadawać znaczenie odpowiednie dla pojęcia kryptowaluty (z pominięciem innych wspomnianych środków rozliczeń za dobra i usługi).

${ }^{12}$ Pieniądz elektroniczny w unijnym systemie prawnym definiuje dyrektywa Parlamentu Europejskiego i Rady 2009/110/WE z 16 września 2009 r..., [Dz.Urz. UE L 267 z dnia 10 października 2009: 7-17), zgodnie z którą (art. 2 pkt 2) ,pieniądz elektroniczny” oznacza wartość pieniężną przechowywaną elektronicznie, w tym magnetycznie, stanowiącą prawo do roszczenia wobec emitenta, która jest emitowana w zamian za środki pieniężne w celu dokonywania transakcji płatniczych określonych w art. 4 pkt 5 dyrektywy 2007/64/WE i akceptowana przez osoby fizyczne lub prawne inne niż emitent pieniądza elektronicznego. W przepisach krajowych, definicja pieniądza elektronicznego zawarta jest w art. 2 pkt 21a u.usł.pł., zgodnie z którym pieniądzem elektronicznym jest wartość pieniężna przechowywana elektronicznie, w tym magnetycznie, wydawana, z obowiązkiem jej wykupu, w celu dokonywania transakcji płatniczych, akceptowana przez podmioty inne niż wyłącznie wydawca pieniądza elektronicznego.

${ }^{13}$ Por. Czarnocki [2017: 56] oraz Zacharzewski [2015: 194].

$14 \mathrm{~W}$ wyniku nowelizacji ustaw o podatkach dochodowych wprowadzonych Ustawą z 23 października 2018 r..., [Dz.U. 2018, poz. 2193]. 
w orzecznictwie sądów administracyjnych ${ }^{15}$ i w doktrynie ${ }^{16}$, zgodnie z którą kryptowaluty należy zaliczyć do kategorii praw majątkowych.

$\mathrm{W}$ doktrynie prawa podatkowego ${ }^{17}$ przy definiowaniu praw majątkowych sięga się do wykładni systemowej i powszechnego stosowania tego terminu na gruncie prawa cywilnego. Art. 44 kodeksu cywilnego [Ustawa z 23 kwietnia 1964 r..., tekst jedn., Dz.U. 2019, poz. 1145 ze zm., dalej: k.c.] obejmuje zbiorczo kategorie podmiotowych praw majątkowych. Zgodnie $\mathrm{z}$ definicją zaproponowaną w literaturze [Wolter i in. 2018: 164] podmiotowymi prawami majątkowymi są prawa bezpośrednio uwarunkowane interesem ekonomicznym ich podmiotu; uznaje się przy tym, iż bez znaczenia jest, czy za określone prawo można uzyskać realnie wartość majątkową w obrocie bądź wręcz przeciwnie wskazuje się, iż prawem majątkowym jest jedynie prawo posiadające wartość majątkową ustaloną według zasad rynkowych [Romanowski 2006: 30]. Kryptowaluty można zaliczyć do praw majątkowych ${ }^{18} \mathrm{w}$ obydwu tych ujęciach; pozostają one $\mathrm{W}$ ścisłym powiązaniu $\mathrm{z}$ ekonomicznym interesem uprawnionego, związane są z jego majątkiem i charakteryzują się dwoma podstawowymi cechami, $\mathrm{tj} .:$ mogą być przedmiotem obrotu i posiadają określoną wartość majątkową. Te cechy zarazem wyznaczają podstawowy zakres problemowy tematyki podatkowego ujęcia kryptowalut.

\section{UJĘCIE KRYPTOWALUT DLA CELÓW PODATKOWYCH - ZAKRES PROBLEMOWY}

Zasadniczo można dokonać następującego pogrupowania różnych sposobów pozyskania kryptowaluty:

- wytworzenie we własnym zakresie, tzw. „wykopanie”,

- odpłatne nabycie,

- nieodpłatne nabycie (w drodze darowizny bądź dziedziczenia),

która to kryptowaluta następnie może zostać odpłatnie zbyta w zamian za prawny środek płatniczy (sprzedaż kryptowaluty), wykorzystana do „zapłaty” za towar, usługę lub prawo majątkowe (funkcja płatnicza kryptowaluty) albo nieodpłatnie przekazana (darowizna kryptowaluty). Wszystkie te kwestie wymagają analizy w zakresie podatków dochodowych, w szczególności co do: powstania przychodu z kryptowaluty i zakwalifikowania go do odpowiedniego źródła

${ }^{15}$ Zob. wyrok NSA z 6 marca 2018 r. [II FSK 488/16], a później wyrok WSA w Olsztynie z 9 maja 2018 r. [I SA/Ol 202/18].

${ }^{16}$ Zob.: Dąbrowska [2017: 58]; Prokurat [2015: 25].

${ }^{17}$ Zob. np. Gomułowicz i Małecki [2003: 190-192].

${ }^{18} \mathrm{~W}$ doktrynie prezentowane są też poglądy odmienne (zob.: Stolarski 2018: 29 i przywołana tam literatura); analiza w tym zakresie wykracza jednak poza ramy tematyczne niniejszego opracowania. 
przychodów, ustalenia kosztów uzyskania przychodu oraz momentów rozpoznania przychodów i potrącenia kosztów.

Zdarzenia te generują też potencjalnie możliwe opodatkowanie $\mathrm{z}$ tytułu obrotu kryptowalutą, czyli wymagają analizy w zakresie podatku od towarów i usług lub podatku od czynności cywilnoprawnych.

W końcu należy zwrócić uwagę, iż zarówno pierwotne, jak i w ramach tzw.: obrotu wtórnego, wejście w posiadanie waluty wirtualnej skutkuje powiększeniem majątku jej użytkownika o wartość kryptowaluty, co rozszerza zakres problematyki prawno-podatkowego ujęcia kryptowaluty na zagadnienia z zakresu podatków majątkowych.

\section{WYMIANA KRYPTOWALUTY NA PRAWNE ŚRODKI PŁATNICZE A PODATKI DOCHODOWE}

Najbardziej bezproblemowe wydawać by się mogło zbycie kryptowaluty w drodze jej wymiany na prawne środki płatnicze. Taka transakcja - przekazanie jednostek kryptowaluty $\mathrm{w}$ zamian za określoną sumę pieniężną $\mathrm{w}$ legalnym pieniądzu - stanowi realizację umowy sprzedaży [Zacharzewski 2015: 187]. Niemniej jednak, nawet w tym przypadku, kwestie $\mathrm{z}$ tym związane budziły pewne wątpliwości wobec licznych alternatywnych wariantów podatkowego ujęcia takich transakcji. W stanie prawnym obowiązującym do końca $2018 \mathrm{r}$. organy podatkowe uznawały przychód ze sprzedaży kryptowalut za przychód z odpłatnego zbycia praw majątkowych ${ }^{19}$ (opodatkowany na zasadach ogólnych), o ile podatnik nie prowadził działalności gospodarczej, w ramach której dokonywał transakcji związanych z kryptowalutami - wtedy bowiem przychód powinien zostać zakwalifikowany do źródła pozarolnicza działalność gospodarcza ${ }^{20}$, z której dochód mógł być opodatkowany według skali lub 19\% stawki podatku liniowego (ewentualnie w formie ryczałtu od przychodów ewidencjonowanych ${ }^{21}$ ). Wielość wariantów rozliczenia transakcji takich samych co do swej istoty budzić

19 Zob. np.: Interpretacja Dyrektora Izby Skarbowej w Warszawie z 25 lutego 2014 r. [IPPB2/415-842/13-2/MK], Interpretacja Dyrektora Izby Skarbowej w Warszawie z 26 czerwca 2014 r. [IPPB1/415-276/14-4/EC], Interpretacja Dyrektora Izby Skarbowej w Poznaniu z 2 października 2014 r. (ILPB2/415-741/14-2/TR), Interpretacja Dyrektora Krajowej Informacji Skarbowej z 3 kwietnia 2017 r. [2461-IBPB-2-2.4511.12.2017.2.BF].

${ }^{20} \mathrm{Na}$ gruncie przepisów ustawy o podatku dochodowym od osób prawnych ta dychotomia oczywiście nie występowała.

${ }^{21}$ Zob.: Interpretacje Dyrektora Izby Skarbowej w Łodzi z 18 lipca 2014 r. [IPTPB1/415220/14-5/KSU i IPTPB1/415-221/14-10/KSU] oraz Interpretacja Dyrektora Izby Skarbowej w Poznaniu z 30 października 2014 r. [ILPB1/415-746/14-4/AA]. Polemikę co do prawidłowości takiego stanowiska przedstawia: Prokurat [2015: 29]. 
mogła poważne zastrzeżenia co do spójności ${ }^{22}$ i podatkowej neutralności ${ }^{23}$ ich ujęcia. Od 2019 r. te różne formy rozliczenia zostały zastąpione jedną, polegającą na ujmowaniu przychodów ze zbycia kryptowaluty jako przychodów z: kapitałów pieniężnych (w przypadku podatników podatku dochodowego od osób fizycznych) albo zysków kapitałowych (w przypadku podatników podatku dochodowego do osób prawnych) i opodatkowaniu powstałych z tego tytułu dochodów jednolitą stawką podatkową w wysokości 19\% [art. 30b ust. 1a u.p.d.o.f. oraz art. 22 d ust. 1 u.p.d.o.p.].

\section{OPODATKOWANIE ZYSKU ZE ZBYCIA KRYPTOWALUT OD 2019 ROKU}

$\mathrm{Na}$ gruncie przepisów ustawy o podatku dochodowym od osób fizycznych przychody z odpłatnego zbycia waluty wirtualnej należy zaliczyć do przychodów z kapitałów pieniężnych (art. 17 ust. 1 pkt 11 u.p.d.o.f.), a na gruncie przepisów ustawy o podatku dochodowym od osób prawnych przychody z odpłatnego zbycia waluty wirtualnej należy zakwalifikować jako przychody z zysków kapitałowych (art. 7b ust.1 pkt 6 lit. f) u.p.d.o.p.); dotyczy to też przychodów uzyskanych w ramach prowadzonej działalności gospodarczej ${ }^{24}$.

${ }^{22}$ Zasada spójności oznacza, że jeżeli dwie transakcje mają taki sam skutek gospodarczy, to powinny one mieć taki sam skutek podatkowy. W doktrynie formułuje się zasadę wewnętrznej spójności i zasadę zewnętrznej spójności. Zasada wewnętrznej spójności dotyczy spójności między różnymi podatkami oraz ich szczegółowej konstrukcji. Zasada zewnętrznej spójności odnosi się natomiast do konieczności synchronizacji ustawodawstwa podatkowego, uwzględniającej standardy wspólnotowe i międzynarodowe [Gomułowicz i Małecki 2013: 240].

${ }^{23}$ Neutralność podatkowa oznacza, że podatki nie wpływają na decyzje przedsiębiorców dotyczące wyboru formy prawnej, miejsca prowadzenia działalności gospodarczej, ani sposobu jej finansowania [Company Taxation in the Internal Market 2001: 2; Kotowska 1998: 132]. Zapewnia brak oddziaływania podatków na konkurencje gospodarcza $w$ obrębie danego rynku, albo (...) sytuację, w której podatki determinuja dziatania podatnika funkcjonujacego w określonych warunkach gospodarczych w możliwie najmniejszym stopniu [Kiszka 2003: 3]. W literaturze taką cechę prawa podatkowego określa się jako neutralność ekonomiczną prawa podatkowego, wskazując, iż system prawa podatkowego nie powinien stanowić autonomicznej i samoistnej przesłanki decyzyjnej podatników [Modzelewski (red.) 2008: 33]. Zasada neutralności podatkowej opiera się na założeniu, iż inwestycje o podobnym charakterze nie powinny być obłożone różnym ciężarem podatkowym tylko z uwagi na odmienne miejsce ich dokonywania, źródło finansowania czy formę prawną, a podatnicy powinni zachowywać się przy uwzględnieniu istniejących uregulowań podatkowych tak samo, jak w hipotetycznej sytuacji ich nieistnienia. W swoich decyzjach mają uwzględniać przede wszystkim czynniki gospodarcze, dzięki czemu struktura inwestycji i działalność gospodarcza są bardziej efektywne [Hamaekers i in. 2006: 66].

${ }^{24} \mathrm{Z}$ wyjątkiem działalności gospodarczej polegającej na świadczeniu usług w zakresie: wymiany pomiędzy walutami wirtualnymi i środkami płatniczymi, wymiany pomiędzy walutami wirtualnymi, pośrednictwa $\mathrm{w}$ tych wymianach lub prowadzenia rachunków prowadzonych $\mathrm{w}$ formie elektronicznej zapewniających osobom uprawnionym możliwość korzystania z jednostek walut wirtualnych, w tym przeprowadzania transakcji ich wymiany [art. 17 ust. $1 \mathrm{~g}$ u.p.d.o.f. lub 
Obecnie zatem, wszystkie przychody osiągnięte z tytułu sprzedaży wirtualnych walut, niezależnie od wysokości osiągniętego przychodu (dochodu) i bez względu, czy następuje to w ramach prowadzenia działalności gospodarczej, należy zakwalifikować do przychodów z kapitałów pieniężnych (zysków kapitałowych) opodatkowanych stawką w wysokości 19\%. Oznacza to, iż przedsiębiorcy nie mogą łączyć dochodów ze sprzedaży wirtualnych walut z pozostałymi dochodami z prowadzonej działalności gospodarczej; dochodów tych nie łączy się też $\mathrm{z}$ dochodami z odpłatnego zbycia papierów wartościowych lub pochodnych instrumentów finansowych, co wynika wprost $z$ art. $30 \mathrm{~b}$ ust. $5 \mathrm{~d}$ u.p.d.o.f. Dochodów z odpłatnego zbycia walut wirtualnych nie łączy się też z innymi dochodami (przychodami) podatnika podatku dochodowego od osób prawnych (art. 22d ust. 4 u.p.d.o.p.). Jednak, jeśli cały dochód podatnika podatku dochodowego od osób fizycznych (nie tylko ze sprzedaży kryptowaluty) przekroczy $1 \mathrm{mln} z$ z , to wtedy podatnik powinien dodatkowo uiścić daninę solidarnościową w wysokości 4\% od uzyskanego dochodu powyżej $1 \mathrm{mln}$ zł [art. 30h ust. 2 u.p.d.o.f.]. Z kolei w przypadku podatników podatku dochodowego od osób prawnych przychód ze sprzedaży kryptowaluty jest uwzględniany w kwocie przychodów, której przekroczenie (1 200000 euro) może skutkować utratą prawa do stosowania stawki $9 \%$ dla opodatkowania pozostałych dochodów [art. 19 ust. 1 pkt 2 u.p.d.o.p.].

Z punktu widzenia postulatów spójności i neutralności podatkowej, zapewnienie w systemie podatków dochodowych od 2019 r. dla wszystkich podatników, zarówno podatku dochodowego od osób fizycznych, jak i podatku dochodowego od osób prawnych, niezależnie od tego, czy obrót kryptowalutą dokonywany jest w ramach działalności gospodarczej czy też poza nią, opodatkowania na takich samych zasadach i na takim samym poziomie (stawką 19\%), należy ocenić pozytywnie. Jednakże powstaje pytanie, czy sam (obecnie ujednolicony) sposób opodatkowania jest odpowiedni do zdolności podatkowej podatników? Wiąże się to w szczególności z ograniczonymi możliwościami zaliczania do kosztów uzyskania przychodów wydatków związanych z walutami wirtualnymi. To ograniczenie budzi wątpliwości co do tego, czy opodatkowaniu rzeczywiście podlega dochód czy faktycznie jednak przychód uzyskany z ich zbycia?

art. 7 b ust. 3 u.p.d.o.p. w zw. z art. 2 ust. 1 pkt 12 u.p.p.f.t.]. Zob. też: Interpretacje Dyrektora Krajowej Informacji Skarbowej z 8 maja 2019 r. [0113-KDIPT2-3.4011.100.2019.2.PRz] i z 30 maja 2019 r. [0114-KDIP2-2.4010.69.2019.4.AG]. 


\section{OPODATKOWANIE DOCHODU CZY PRZYCHODU ZE ZBYCIA KRYPTOWALUT?}

Zgodnie $\mathrm{z}$ art. $30 \mathrm{~b}$ ust. $1 \mathrm{~b}$ u.p.d.o.f. (art. $22 \mathrm{~d}$ ust. 2 u.p.d.o.p.) dochodem $\mathrm{z}$ odpłatnego zbycia walut wirtualnych jest osiągnięta $\mathrm{w}$ roku podatkowym różnica między sumą przychodów uzyskanych z tytułu ich odpłatnego zbycia a kosztami uzyskania przychodów określonymi na podstawie art. 22 ust. 14-16 u.p.d.o.f. (art. 15 ust. 11-13 u.p.d.o.p.), które stanowią udokumentowane wydatki bezpośrednio poniesione na nabycie walut wirtualnych oraz koszty związane $\mathrm{z}$ ich zbyciem $^{25}$. Po pierwsze zatem wydatki należy odpowiednio udokumentować, a po drugie nie mogą to być wydatki pośrednio związane z nabyciem kryptowalut.

Warunek „bezpośredniości” jest szczególnie problematyczny w przypadku kosztów wydobycia zbywanych następnie kryptowalut. Wydobywanie bitcoinów (i innych kryptowalut) wymaga inwestycji w specjalistyczny sprzęt (tzw. koparki), którego koszty mogą wynosić nawet do kilkudziesięciu tysięcy złotych [Homa 2015: 63, 115 i n.]. Brak możliwości rozliczenia takich wydatków (podobnie jak w przypadku kosztów z tytułu zwiększonego poboru prądu przez koparki) z uwagi na ich uznawanie za koszty pośrednie ${ }^{26}$ - jest bardzo dotkliwy, jakkolwiek prezentowany jest też pogląd ${ }^{27}$, iż wydatki takie należy traktować jako podlegające odliczeniu koszty bezpośrednie. Niewątpliwie pozbawienie podatników możliwości podatkowego rozliczenia jednych z najważniejszych i w pełni uzasadnionych ekonomicznie wydatków związanych z kryptowalutami, budzi poważne wątpliwości co do adekwatności takiego stanowiska do rzeczywistości gospodarczej pozyskiwania kryptowalut.

Kolejnym częstym problemem, wynikającym z istoty transakcji kryptowalutowych, jest brak możliwości udokumentowania poniesionych wydatków w sposób wymagany przez organy podatkowe. Transakcje te często są anonimowe, a jedyne dokumenty potwierdzające nabycie stanowią dowody przelewu (wynika to z zasad stosowanych przez wyspecjalizowane giełdy, w przypadku których podatnik może jedynie pokazać wpłaty i wypłaty na swój tzw. wallet, bez możliwości przyporządkowania kosztów i przychodów do konkretnej transakcji). Niektóre ${ }^{28}$ organy podatkowe $\mathrm{w}$ takich sytuacjach odmawiają prawa do

${ }^{25} \mathrm{~W}$ tym udokumentowane wydatki poniesione na rzecz podmiotów, o których mowa w art. 2 ust. 1 pkt 12 u.p.p.p.f.t.

${ }^{26}$ Interpretacja Dyrektora Izby Skarbowej w Warszawie z 10 lipca 2014 r. [IPPB5/423397/14-4/MW], Interpretacja Dyrektora Krajowej Informacji Skarbowej z 2 marca 2019 r. [0113KDIPT3.4011.599.2018.1.SK].

${ }^{27}$ Interpretacja Dyrektora Krajowej Informacji Skarbowej z 19 października 2018 r. [0112KDIL3-1.4011.350.2018.1.AN].

${ }^{28}$ Zdarzają się też bowiem organy takie prawo przyznające, zob. Interpretacja Dyrektora Izby Skarbowej w Warszawie z 26 czerwca 2014 r. [IPPB1/415-276/14-4/EC]. 
rozpoznania kosztu z tytułu nabycia kryptowalut ze względu na brak odpowiedniego udokumentowania ${ }^{29}$, co jednak nie znajduje uznania $\mathrm{w}$ orzecznictwie sądowo-administracyjnym ${ }^{30}$.

Pewne problemy występują ponadto w sytuacji zbywania kryptowalut, które były nabywane po różnych kursach. Dla prawidłowego rozliczenia staje się bowiem konieczne ustalenie, która $\mathrm{z}$ nabytych walut sprzedawana jest $\mathrm{w}$ danym momencie. Przepisy ustaw o podatkach dochodowym nie zawierają uregulowań dotyczących kolejności sprzedaży kryptowalut. Tutaj akurat można się zgodzić ze stanowiskiem organów podatkowych ${ }^{31}$, prezentowanym też w orzecznictwie sądowo-administracyjnym ${ }^{32}$, z którego wynika, iż podatnik powinien prowadzić dokumentację zakupu i sprzedaży kryptowaluty w sposób pozwalający na jej identyfikację, a jeśli nie będzie takiej możliwości, to podatnik powinien zastosować metodę ,pierwsze przyszło, pierwsze wyszło” (FIFO).

Przedstawione kwestie (warunek bezpośredniości, udokumentowania i identyfikacji), stanowią wyzwania, którym niesprostanie może skutkować faktycznym opodatkowaniem przychodu, a nie dochodu, $\mathrm{z}$ odpłatnego zbycia walut wirtualnych, powodującym nadmierny ciężar podatkowy.

\section{NEUTRALNOŚĆ PODATKOWA WYKOPANIA KRYPTOWALUT}

Pozyskanie kryptowalut może następować na rynku pierwotnym albo wtórnym. Pierwotne nabycie następuje przez wykopanie kryptowaluty; obecnie jednak większość nabyć następuje $\mathrm{w}$ ramach wtórnego pozyskania $\mathrm{z}$ rynku, tj. na giełdzie, w kantorze, w tzw. bitcoinmatach ${ }^{33}$, w wirtualnych sklepach czy bezpośrednio od osoby, która je posiada [Bala i in. 2016: 86], w tym także w takie tradycyjne sposoby jak zakup, zamiana, darowizna, itd. [Szostek 2018: 80].

Kopaniem kryptowaluty nazywany jest proces tworzenia nowych bloków w łańcuchu. Utworzenie nowego bloku wiąże się z powstaniem nowej wartości kryptowaluty, która jest zapłatą za znalezienie odpowiedniej wartości funkcji skrótu przypisanej rozwiązanemu blokowi. Nowo powstała wartość jest rezulta-

${ }^{29}$ Zob. np.: Interpretacja Dyrektora Izby Skarbowej w Katowicach z 29 lipca 2015 r. [IBPB1-1/4511-107/15/AB] czy Interpretacja Dyrektora Krajowej Informacji Skarbowej z 3 kwietnia 2017 r. [2461-IBPB-2-2.4511.12.2017.2.BF].

${ }^{30}$ WSA w Warszawie w wyroku z 11 września 2015 r. [III SA/Wa 3374/14] stwierdził, że skoro giełdowy obrót kryptowalutami jest anonimowy i nie można pozyskać dokumentów potwierdzających dane stron transakcji, to do udokumentowania kosztu wystarczą dokumenty, które jednoznacznie będą potwierdzać zakup bitcoinów (ich ilość, cenę zakupu, itp.).

${ }^{31}$ Interpretacja Dyrektora Izby Skarbowej w Warszawie z 26 czerwca 2014 r. [IPPB1/415276/14-4/EC]

${ }^{32}$ Wyrok WSA w Warszawie z 11 września 2015 r. [III SA/Wa 3374/14].

${ }^{33}$ Zob. Homa [2015: 104-106]. Pierwszy bitcoinowy bankomat uruchomiono w październiku 2013 r. w Kanadzie [Kopańko i Kozłowski 2015: 127]. 
tem kopania. Użytkownik dostarczający mocy obliczeniowej do kopania otrzymuje kryptowalutę za oddanie do dyspozycji mocy obliczeniowej swojego komputera i za potwierdzenie transakcji występujących w sieci kryptowaluty, a kryptowaluta ma określoną rynkowo wartość, więc osoba, która nabędzie ją w ten sposób, zwiększa swój majątek (podobnie zresztą, jak osoba nabywająca kryptowalutę $\mathrm{w}$ inny $\mathrm{z}$ możliwych sposobów). Powstaje więc pytanie, czy osoba zajmująca się wydobyciem, powinna rozpoznać przychód z tego tytułu już na etapie „wykopania” bitcoina. Na to pytanie należy udzielić odpowiedzi negatywnej, gdyż na skutek wykopania nie dochodzi do otrzymania żadnych praw ani należności. Nie ma również możliwości zakwalifikowania tej sytuacji jako darowizny ${ }^{34}$. Wejście $\mathrm{w}$ posiadanie kryptowaluty $\mathrm{w}$ pierwotny sposób bliższe jest działalności wydobywczej (produkcyjnej), w której dopiero sprzedaż wytworzonego produktu wiąże się z przychodem. Samo wykopanie kryptowaluty nie powinno zatem powodować powstania obowiązku podatkowego w podatku dochodowym. Takie podejście, wcześniej już prezentowane przez organy podatkowe $^{35}$, obecnie wynika wprost $\mathrm{z}$ brzmienia przepisów ${ }^{36}$, zgodnie $\mathrm{z}$ którymi obowiązek podatkowy kreuje jedynie odpłatne zbycie wirtualnych walut. Oznacza to, iż osoby zajmujące się wykopywaniem kryptowalut mają obowiązek wykazać przychód dopiero na etapie zbycia waluty wirtualnej. Samo wykopanie kryptowaluty pozostaje zatem obojętne podatkowo.

\section{8. „ZAPŁATA” KRYPTOWALUTA ZA TOWARY, USŁUGI LUB PRAWA MAJĄTKOWE}

Podstawową funkcją kryptowaluty jest funkcja płatnicza; przypomnieć należy, iż u podstaw jej stworzenia leżała koncepcja płacenia bez pośredników finansowych. I wprawdzie kryptowaluta nie ma prawnego statusu środka płatniczego, jednakże faktycznie może tak funkcjonować, kiedy służy nabyciu towarów, usług lub praw majątkowych (za które ,płaci się" walutą wirtualną). Powstaje w związku z tym fundamentalne pytanie, jakie konsekwencje podatkowe mają takie transakcje?

Zgodnie z art. 17 ust. 1f u.p.d.o.f. przez odpłatne zbycie waluty wirtualnej rozumie się wymianę waluty wirtualnej na prawny środek płatniczy, towar, usługę lub prawo majątkowe inne niż waluta wirtualna lub regulowanie innych zobowiązań walutą wirtualną. $\mathrm{Z}$ kolei na podstawie art. $7 \mathrm{~b}$ ust.1 pkt 6 lit. f) u.p.d.o.p. przychodem z zysków kapitałowych jest przychód $\mathrm{z}$ wymiany waluty wirtualnej na środek płatniczy, towar, usługę lub prawo majątkowe inne niż

\footnotetext{
${ }^{34}$ Por. Prokurat [2015: 26].

${ }^{35}$ Zob. m.in. Interpretacja Dyrektora Krajowej Informacji Skarbowej z 22 grudnia 2017 r. [0113-KDIPT2-1.4011.472. 2017.1.DJD].

${ }^{36}$ Zob. art. $30 \mathrm{~b}$ ust. 1a u.p.d.o.f. oraz art. $7 \mathrm{~b}$ ust.1 pkt 6 lit. f) u.p.d.o.p.
} 
waluta wirtualna lub $\mathrm{z}$ regulowania innych zobowiązań walutą wirtualną. Z przytoczonych przepisów wynika neutralność podatkowa wymiany jednej waluty wirtualnej na inną walutę wirtualną. Oznacza to, że w razie, gdy osoba zajmująca się handlem kryptowalutami dokonuje ich zamiany, nie musi ustalać przychodu $\mathrm{z}$ takiej transakcji. Jednocześnie jednak, zgodnie $\mathrm{z}$ art. 23 ust.1 pkt 38d u.p.d.o.f. oraz art. 16 ust. 1 pkt 75 u.p.d.o.p., poniesionych wydatków związanych z zamianą waluty wirtualnej na inną walutę wirtualną nie może potem zaliczyć do kosztów uzyskania przychodów.

Natomiast w sytuacji, gdy wirtualna waluta jest wymieniana na towary, usługi lub prawa majątkowe inne niż kryptowaluty, powstaje $\mathrm{z}$ tego tytułu przychód u obydwu stron transakcji traktowanej jako rodzaj transakcji barterowej ${ }^{37}$. Rozróżnić przy tym trzeba przychód u sprzedawcy towaru, usługi lub prawa majątkowego, za które otrzymuje on „zapłatę” w postaci kryptowaluty. Powinien on wykazać przychód w odpowiedniej wysokości, od którego to przychodu może odjąć koszty nabycia, wytworzenia lub wykonania towaru, usługi czy prawa majątkowego, za które otrzymał wirtualną walutę. Takie ujęcie „zapłaty” kryptowalutą po stronie dostawcy towaru, usługi lub prawa majątkowego, nie budzi wątpliwości, oddając istotę jej podstawowej funkcji, tj. funkcji płatniczej. Jednocześnie jednak z przytoczonych przepisów wynika konieczność ustalenia przychodu u nabywcy towaru, usługi lub prawa majątkowego jako przychodu $\mathrm{z}$ odpłatnego zbycia waluty wirtualnej. Takie ujęcie jest konsekwencją tego, iż wirtualna waluta nie jest prawnym środkiem płatniczym i powoduje ono, iż „zapłata" walutą cyfrową jest ujmowana w sposób niezgodny z funkcją, jaką pełni (funkcją płatniczą) i odmiennie niż w przypadku zapłaty za takie same towary, usługi lub prawa majątkowe walutą fiducjarną, które to transakcje w swej istocie ekonomicznej się nie różnią. Kwestia ta (ujęcie podatkowe zgodne albo niezgodne z funkcją płatniczą) wymaga także analizy dla celów podatku od towarów i usług.

\section{KRYPTOWALUTY A VAT}

Podobnie, jak w przypadku podatków dochodowych, także w przypadku podatku od towarów i usług (podatku od wartości dodanej, dalej: VAT) należy rozróżnić zasadniczo dwie sytuacje: sprzedaż kryptowaluty i „,zapłatę” kryptowalutą. Fundamentalną kwestię stanowi przy tym rozstrzygnięcie, czy przekazanie kryptowaluty należy traktować jako świadczenie usług (transakcje związane $\mathrm{z}$ obrotem kryptowalutami nie stanowią bowiem $\mathrm{z}$ pewnością dostawy towa-

\footnotetext{
${ }^{37}$ Szerzej zob. Zacharzewski [2015: 187-188].
} 
rów ${ }^{38}$ ), a dalej: opodatkowane czy zwolnione z opodatkowania jako transakcje (usługi) finansowe, czy też należy je uznać za dokonanie płatności innym środkiem płatniczym aniżeli prawny środek płatniczy (funkcja płatnicza).

W tym drugim przypadku dokonanie ,zapłaty” kryptowalutą nie rodzi konsekwencji na gruncie przepisów o VAT, gdyż nie stanowiąc ani dostawy towarów, ani świadczenia usług, nie mieści się w katalogu czynności podlegających opodatkowaniu ${ }^{39}$ tym podatkiem. Takie stanowisko zajął rzecznik generalny w opinii z 16 lipca 2015 r. w sprawie C-264/14 [Opinia Rzecznika Generalnego..., Sprawa C-264/14], odwołując się do orzeczenia TSUE w sprawie C-172/96 [Wyrok TSUE z 14 lipca 1998 r. w sprawie C-172/96...], wskazując, iż przekazanie środków płatniczych jako takich nie stanowi zdarzenia powodującego powstanie obowiązku podatkowego w VAT, a może być jedynie świadczeniem wzajemnym za opodatkowane świadczenie (towar lub usługę), gdyż VAT jest podatkiem obciążającym ostateczną konsumpcję dóbr. Istniejące prawne środki płatnicze nie posiadają zasadniczo innej praktycznej możliwości ich wykorzystania niż jako środek płatniczy, a ich funkcja ogranicza się w ramach transakcji do ułatwienia wymiany dóbr w gospodarce; nie są one jednak jako takie konsumowane lub używane jako dobra. To, co obowiązuje w stosunku do prawnych środków płatniczych, powinno też obowiązywać wobec innych środków płatniczych, których funkcja się do tego ogranicza. Nawet w wypadku, gdy takie środki nie są gwarantowane i kontrolowane, jeśli spełniają jednak takie same funkcje jak prawne środki płatnicze, to powinno się $\mathrm{z}$ nimi postępować - zgodnie z zasadą neutralności podatkowej - w taki sam sposób. Zgodnie z tym tokiem rozumowania „zapłata” kryptowalutą nie powoduje w ogóle powstania obowiązku podatkowego na gruncie przepisów o VAT i nie ma zatem konieczności dalszej analizy co do podstaw jej ewentualnego zwolnienia z opodatkowania ${ }^{40}$.

${ }^{38}$ Zgodnie z art. 14 ust. 1 Dyrektywy Rady 2006/112/WE z 28 listopada 2006 r..., [Dz. Urz. UE L 347 z 11.12.2006: 1-118, dalej: dyrektywa] dostawa towarów oznacza przeniesienie prawa do rozporządzania rzeczą jak właściciel (art. 7 ust. 1 u.p.t.u.), a kryptowaluta, w świetle regulacji zawartej w art. 45 k.c., nie jest rzeczą (por. Dąbrowska [2017: 59]; Zacharzewski [2015: 1133]. Nie jest też energią, ani inną kategorią zrównaną z rzeczami na podstawie art. 15 dyrektywy (art. 2 pkt 6 u.p.t.u.). Skoro jednocześnie na podstawie art. 24 ust. 1 dyrektywy (art. 8 ust. 1 u.p.t.u.) świadczenie usług oznacza każdą transakcję, która nie stanowi dostawy towarów, to obrót kryptowalutami może potencjalnie stanowić świadczenie usług. Tak też wskazywały polskie organy podatkowe, kwalifikując obrót bitcoinami jako świadczenie usług (np. Dyrektor Izby Skarbowej w Katowicach w interpretacji z 21 czerwca 2013 r., [IBPP2/443-258/13/ICz]).

${ }^{39}$ Zawartym w art. 2 ust. 1 dyrektywy (art. 5 ust. 1 u.p.t.u.).

${ }^{40}$ Tak też wskazał Dyrektor Izby Skarbowej w Poznaniu w interpretacji z 8 stycznia 2014 r. [ILPP1/443-910/13-2/AWa], w której stwierdził, iż umorzenie dlugu kontrahentom, jak również uregulowanie zobowiązá́ za pomoca bitcoinów nie będzie rodziło $w$ spółce konsekwencji na gruncie podatku VAT, gdyż nie stanowi ani dostawy towarów, ani świadczenia usług i nie będzie mieścito się $w$ katalogu czynności podlegajacych opodatkowaniu podatkiem VAT, wymienionych w przepisie art. 5 ust. 1 u.p.t.u. 
To ewentualne zwolnienie do zastosowania to zwolnienie przewidziane dla transakcji (usług) finansowych ${ }^{41}$, co do którego możliwości zastosowania dla transakcji z użyciem kryptowaluty wypowiedział się TSUE w wyroku z dnia 22 października 2015 roku w sprawie C-264/14. Chodzi tutaj o sytuacje związane $\mathrm{z}$ obrotem kryptowalutami (sprzedażą kryptowalut - zamianą ich na walutę tradycyjną, a nie „zapłatę” kryptowalutą). W wyroku tym Trybunał wskazał, iż bezspornym jest to, że jedynym przeznaczeniem wirtualnej waluty jest funkcja środka płatniczego ${ }^{42}$. Trybunał orzekł, iż świadczenie usług, które polegają na wymianie walut tradycyjnych na jednostki wirtualnej waluty i odwrotnie, dokonywane za zapłatą kwoty odpowiadającej marży wynikającej z różnicy pomiędzy ceną, po jakiej przedsiębiorca nabywa waluty, a ceną, po jakiej je sprzedaje klientom, stanowi transakcje zwolnione z podatku od wartości dodanej. Orzeczenie to ma moc wiążącą w państwach członkowskich dla sądów krajowych oraz organów podatkowych, a tym samym, obrót walutami wirtualnymi jest zwolniony z podatku VAT, analogicznie jak i inne transakcje dotyczące walut i innych prawnych środków płatniczych. Przedmiotowy wyrok znalazł odzwierciedlenie $w$ późniejszych interpretacjach organów podatkowych ${ }^{43}$ oraz w orzecznictwie sądów administracyjnych ${ }^{44}$. Zaznaczyć jednak trzeba, iż takie podejście oznacza brak prawa do odliczenia podatku naliczonego od zakupów wykorzystywanych na potrzeby działalności w zakresie obrotu kryptowaluta$\mathrm{mi}^{45}$. Należy też zauważyć, iż zwolnienie z VAT determinuje brak opodatkowania obrotu kryptowalutami podatkiem od czynności cywilnoprawnych ${ }^{46}$, podczas gdy brak opodatkowania wynikający z braku obowiązku podatkowego na gruncie u.p.t.u. takiego skutku nie ma.

${ }^{41}$ Zawarte w art. 135 ust. 1 lit e) dyrektywy (art. 43 ust. 1 pkt 7 u.p.t.u.).

${ }^{42}$ Pewną polemikę w tym zakresie przedstawia Dudek [2016].

43 Np. Dyrektor Izby Skarbowej w Poznaniu w interpretacji z 6 kwietnia 2016 r. [ILPP5/4512-1-5/16-4/IP] uznał, iż zarówno pozyskiwanie waluty bitcoin w ramach tzw. wykopywania, jak i pozyskiwanie w ramach odpłatnego nabycia od podmiotów trzecich, a następnie zbywanie tak nabytych jednostek w zamian za polskie złote, może być uznane za usługę zwolnioną na podstawie art. 43 ust. 1 pkt 7 u.p.t.u.

${ }^{44}$ Zob. wyrok WSA w Łodzi z 23 marca 2016 r. [I SA/Ld 54/16].

${ }^{45}$ Np.: Dyrektor Krajowej Informacji Skarbowej w interpretacji z 1 grudnia 2017 r. [0111KDIB3-3.4012.122.2017.2.PK], dotyczącej spółki zajmującej się handlem kryptowalutami wydobywanymi przy użyciu własnego oraz leasingowanego sprzętu, stanął na stanowisku, że skoro obrót kryptowalutami stanowi transakcję zwolnioną z VAT, to konsekwencją tego jest brak możliwości odliczenia podatku VAT naliczonego od zakupów, które mają bezpośredni związek z tym obrotem, czyli przykładowo urządzeń służących do ich wydobywania.

${ }^{46}$ Wynika to z art. 2 pkt 4 lit. b) u.p.c.c.; zob. też m.in. Interpretacje Dyrektora Krajowej Informacji Skarbowej z 30 listopada 2017 r. [0111-KDIB4.4014.393.2017.3.PM] i z 24 października 2018 r. [0111-KDIB2-2.4014.99.2018.6.MZ]. 


\section{KRYPTOWALUTY JAKO PRAWA MAJĄTKOWE W PODATKU OD CZYNNOŚCI CYWILNOPRAWNYCH ORAZ W PODATKU OD SPADKÓW I DAROWIZN}

Punkt wyjścia dla podatkowego ujęcia obrotu kryptowalutami w podatku od czynności cywilnoprawnych stanowi traktowanie ich sprzedaży lub zamiany jako obrotu prawami majątkowymi, co jest objęte zakresem przedmiotowym ustawy o podatku od czynności cywilnoprawnych [art. 1 ust. 1 pkt a) u.p.c.c.]. Jak wskazał NSA w wyroku II FSK 488/16 kryptowaluty należy traktować jako prawa majątkowe, z czego Minister Finansów w komunikacie z kwietnia 2018 r. [Komunikat Ministra Finansów z 4 kwietnia 2018 r..., www.mf.gov.pl] wywiódł, iż umowa sprzedaży oraz zamiany kryptowaluty podlega opodatkowaniu podatkiem od czynności cywilnoprawnych. W przypadku umowy sprzedaży obowiązek podatkowy spoczywa na kupującym [art. 4 pkt 1 u.p.c.c.], a w przypadku zamiany - solidarnie na kupującym i sprzedającym [art. 4 pkt 2 u.p.c.c.]; stawka podatku wynosi $1 \%$ [art. 7 ust. 1 pkt $1-2$ u.p.c.c.], a podstawa opodatkowania ustalana jest jako wartość rynkowa nabywanego prawa majątkowego [art. 6 ust. 1 pkt 1-2 u.p.c.c.] (zbywanej kryptowaluty). Oczywiście dotyczy to sytuacji obrotu tzw. nieprofesjonalnego, tzn. takiego, w którym nie podstaw do wyłączenia stosowania przepisów u.p.c.c. z uwagi na to, że obrót podlega opodatkowaniu podatkiem od towarów i usług albo przynajmniej jedna ze stron jest zwolniona od podatku od towarów i usług z tytułu dokonania tej czynności obrotu [art. 2 pkt 4 u.p.c.c.]. W przypadku bowiem obrotu tzw. profesjonalnego transakcje $\mathrm{w}$ jego ramach pozostają poza zakresem u.p.c.c.

Przywołany powyżej komunikat, w zakresie opodatkowania transakcji związanych z obrotem kryptowalutami podatkiem od czynności cywilnoprawnych wzbudził kontrowersje i spowodował falę krytyki ${ }^{47}$; zarzucono, że takie podejście nie uwzględnia realiów obrotu kryptowalutami, w przypadku których dochodzi często do bardzo licznych transakcji przeprowadzanych jednego dnia. Składanie zatem deklaracji podatkowej dla każdej transakcji i opłacanie każdorazowo podatku, byłoby niezwykle uciążliwe, a podatek mógłby znacznie przekroczyć wartość nie tylko zysku, ale w ogóle zainwestowanych środków w kryptowaluty. Doraźnie problem został rozwiązany w wyniku zaniechania poboru podatku na rozporządzenia Ministra Finansów ${ }^{48}$, w uzasadnieniu do którego

${ }^{47}$ Zob. np.: www3; www7.

48 Rozporządzenie Ministra Finansów z 11 lipca 2018 r..., [Dz.U. 2018, poz. 1346 ze zm.], które obowiązywało pierwotnie do 30 czerwca 2019 r.; następnie na skutek nowelizacji rozporządzeniem Ministra Finansów z 24 czerwca 2019 r. zmieniającym rozporządzenie w sprawie zaniechania poboru podatku od czynności cywilnoprawnych od umowy sprzedaży lub zamiany waluty wirtualnej [Dz.U. 2019, poz. 1184] miało obowiązywać do 31 grudnia 2019 r., a po kolejnej nowelizacji (rozporządzeniem Ministra Finansów z 18 grudnia 2019 r. zmieniającym rozporządzenie 
wskazano, iż uwzględniając specyfikę handlu walutami wirtualnymi, który sprowadza się do obracania tymi prawami majątkowymi przez ich zakup, sprzedaż $i$ wymiane, a zatem wielokrotnego zawierania umów sprzedaży i zamiany, po stronie podmiotu dokonującego obrotu waluta wirtualna powstać może obowiazek zapłaty podatku $w$ wysokości niejednokrotnie przewyższającej zainwestowane środki. W konsekwencji, stosowanie ścisłej wykładni przepisów ustawy o podatku od czynności cywilnoprawnych może skutkować nałożeniem na podatników obowiązków niemożliwych do wykonania, prowadzacych $w$ wielu przypadkach do konfiskaty majątku, a tym samym naruszeniem konstytucyjnej zasady dotyczacej prawa do ochrony własności. Rozwiązanie to (zaniechanie poboru) jest jednak tymczasowe i należy postulować jak najszybsze docelowe rozstrzygnięcie tej kwestii przez stosowne zmiany w ustawodawstwie podatkowym.

Traktowanie kryptowalut jako praw majątkowych determinuje też pewne skutki na gruncie przepisów o podatku od spadków i darowizn. Zgodnie bowiem $\mathrm{z}$ art. 1 ust. 1 pkt 1 i 2 u.p.s.d. opodatkowaniu podatkiem od spadków i darowizn podlega m.in. nabycie przez osoby fizyczne własności praw majątkowych wykonywanych na terytorium Polski tytułem darowizny lub dziedziczenia. Wobec tego darowizna (odziedziczenie ${ }^{49}$ ) kryptowalut - traktowana jako darowizna (odziedziczenie) praw majątkowych - kreuje obowiązek podatkowy w podatku od spadków i darowizn. Obowiązek podatkowy spoczywa na obdarowanym (spadkobiercy) [art. 5 u.p.s.d.] i powstaje z chwilą wykonania umowy darowizny (przyjęcia spadku) [art. 6 u.p.s.d.]. W przypadku późniejszej sprzedaży kryptowaluty i powstania przychodu z tego tytułu, z uwagi na to, iż przy nabyciu nieodpłatnym, jakim jest zarówno darowizna, jak i dziedziczne, nie występują zasadniczo koszty uzyskania przychodów, powstanie dochód o wartości ceny uzyskanej ze sprzedaży.

\section{PODSUMOWANIE}

Cyfryzacja staje się faktem i wymusza konieczność zaakceptowania nowych narzędzi i instytucji funkcjonujących w przestrzeni internetowej. Jednym z jej aspektów jest technologia blockchain, która wprowadziła do systemu usług finansowych możliwości dokonywania płatności bez pośredników finansowych, a z użyciem kryptowalut - początkowo negowanych albo co najmniej lekceważonych, potem zauważonych i „oswajanych”, aż w końcu (jakkolwiek w róż-

\footnotetext{
w sprawie zaniechania poboru podatku od czynności cywilnoprawnych od umowy sprzedaży lub zamiany waluty wirtualnej [Dz.U. 2019, poz. 2459]) ma obowiązywać do 30 czerwca 2020 r.

${ }^{49}$ Jakkolwiek, jak wskazuje się w literaturze [por. Dąbrowska 2017: 58], kwestia dziedziczenia kryptowalut może budzić pewne problemy natury praktycznej wynikające $\mathrm{z}$ ich anonimowości.
} 
nych państwach na różnym etapie) akceptowanych i regulowanych, w tym także w obszarze prawa podatkowego.

W przypadku Polski taka ewolucja jest wyraźnie widoczna w systemie podatków dochodowych, w przypadku których początkowy chaos wynikający $\mathrm{z}$ problemu umiejscowienia kryptowalut w istniejących ramach prawnych ustąpił wyraźnym regulacjom dotyczącym walut wirtualnych.

Nie można przy tym zapominać o specyfice kryptowalut; jednym z większych problemów z punktu widzenia prawa podatkowego, a korzyści - z punktu widzenia ich użytkowników, jest występujący w przypadku usług finansowych z użyciem kryptowalut ich zdecentralizowany i zanonimizowany charakter, jaki zapewnia technologia blockchain. $\mathrm{Z}$ jednej strony, nie może to zwalniać z obowiązków podatkowych, z drugiej jednak strony należy postulować uwzględnienie przez ustawodawcę i organy podatkowe właśnie tej specyfiki obrotu walutami wirtualnymi. Obecnie bowiem, w istniejącym stanie prawnym i przy prezentowanym przez organy podatkowe podejściu, spełnienie wszystkich warunków dla prawidłowego rozliczenia dochodów z walut wirtualnych może sprawiać pewne problemy. W tym kontekście krytycznie trzeba odnieść się do ograniczenia możliwości rozliczania kosztów związanych z kryptowalutami tylko do kosztów bezpośrednich oraz restrykcyjnego podejścia organów podatkowych do kwestii dokumentowania wydatków na waluty wirtualne. Anonimowość, stanowiąca systemową cechę obrotu wirtualnymi walutami, nie powinna bowiem uniemożliwiać rozliczania kosztów z uwagi na brak możliwości ich standardowego udokumentowania.

Kwestia niedostrzeżenia przez ustawodawcę podatkowego specyfiki obrotu kryptowalutami jest szczególnie dotkliwa w przypadku podatku od czynności cywilnoprawnych, dla potrzeb którego konieczne jest systemowe i docelowe rozwiązanie problemu nadmiernego opodatkowania obrotu kryptowalutami jako prawami majątkowymi, obecnie tymczasowo rozwiązanego przez zaniechanie poboru. Wymaga to jednak zrozumienia, zarówno ze strony ustawodawcy, jak i organów podatkowych, jak kryptowaluty pasują [Homa 2015: 133], a właściwie nie pasują, do ram obecnych regulacji prawnych.

Warto przy tym zadbać, żeby podatkowe ujęcie kryptowalut spełniało warunki spójności, neutralności i pewności. W tym kontekście (zwłaszcza spełnienia postulatu spójności i neutralności) szczególnie pozytywnie należy ocenić jednolite od 2019 r. traktowanie kryptowaluty dla celów obydwu podatków dochodowych. Jednocześnie jednak spowodowało ono pewien „wyłom” w systemie podatkowym, gdyż wprawdzie dla celów podatków dochodowych kryptowaluty już nie są traktowane jak prawa majątkowe, zachowują jednak taki charakter dla celów podatku od czynności cywilnoprawnych i podatku od spadków i darowizn. Ten niejednorodny stan i brak systemowej spójności jeszcze dodatkowo komplikuje odmienne ujęcie kryptowalut dla celów podatku od towarów 
i usług, oparte na funkcji płatniczej walut wirtualnych i faktycznym zrównaniu ich z walutami tradycyjnymi.

Obecnie zatem w polskim systemie podatkowym równolegle do kwalifikacji waluty wirtualnej na potrzeby podatków dochodowych (jako praw majątkowych do 2018 r., a od 2019 r. - kapitałów pieniężnych lub zysków kapitałowych) istnieje odmienna klasyfikacja na potrzeby podatku od towarów i usług, w przypadku którego waluta wirtualna zrównana jest z walutą tradycyjną, podczas gdy z kolei na gruncie przepisów u.p.c.c. i u.p.s.d. waluty wirtualne traktowane są nadal jako prawa majątkowe. Ten brak systemowej spójności należy ocenić krytycznie, postulując jak najszybsze uporządkowanie przepisów podatkowych. Docelowy spójny systemowo stan prawny powinien służyć realizacji zasady pewności, szczególnie ważnej dla przedsiębiorców.

Bardzo istotną w tym kontekście kwestią jest rozstrzygnięcie, jak kryptowaluty, pełniąc w istocie funkcję płatniczą (usługi finansowe bez pośrednictwa banków), mają być traktowanie w systemie podatkowym. Trzeba bowiem mieć świadomość, iż bitcoin (i ewentualnie inne kryptowaluty) jest obecnie środkiem wymiany $^{50}$, przyjmowanym jako zapłata [Barta i Murphy 2018: 91-92] i pełniącym funkcję płatniczą (koncepcja płatności bez pośredników finansowych), jakkolwiek bez uznania za prawny środek płatniczy (w szczególności w polskim systemie prawa). Niemniej jednak waluty wirtualne spełniają rolę środka płatniczego (jakkolwiek nie powszechnie akceptowalnego) i w związku z tym możliwe podejście do ich podatkowego ujęcia jest analogiczne, jak dla prawnych środków płatniczych. Takie podejście, w pewnym zakresie, występuje na potrzeby VAT, niemniej jednak, pomimo jego atrakcyjności, w obecnym stanie prawnym, powoduje ono asymetrię w podatkowym ujęciu transakcji ,zapłaty” kryptowalutą dla celów VAT (zdarzenie obojętne podatkowo) i dla celów podatków dochodowych (zdarzenie kreujące przychód u ,płacącego”).

Przedstawione kwestie nie wyczerpują wszystkich możliwych problemów, jakie na gruncie przepisów prawa podatkowego mogą się wiązać z wykorzystywaniem technologii blockchain w usługach finansowych dla dokonywania płatności z użyciem walut wirtualnych. Związane z tym podatkowe wyzwania warte są uwagi badawczej, gdyż, jak się przewiduje [Boucher i in. 2017], technologia blockchain istotnie wpłynie w najbliższych latach na gospodarkę UE, a Europa nie może od niej uciec. W lutym 2018 r. Komisja Europejska uruchomiła unijne Obserwatorium i Forum ds. Łańcucha Bloków, którego celem ma być przedstawianie najważniejszych postępów w dziedzinie technologii blockchain, wspieranie europejskich podmiotów oraz zwiększenie współpracy UE z zainteresowanymi stronami działającymi w tym obszarze [Komisja Europejska - Komunikat prasowy, 2018]. Komisja wskazała, iż technologia łańcucha bloków w znaczacy

\footnotetext{
${ }^{50}$ Por. Prokurat [2015: 24].
} 
sposób wpłynie na ustugi cyfrowe oraz spowoduje przekształcenie modeli biznesowych $w$ wielu obszarach działalności [www4], a wśród licznych technologii stymulujacych innowacje cyfrowe system ,blockchain” może doprowadzić do poważnch transformacji $w$ obszarze ustug i rynków finansowych [Komisja Europejska - Komunikat prasowy, 2018].

Warto zatem przygotować się do tego, aby usługi finansowe z zastosowaniem technologii blockchain dla płatności bezpośrednich, nie stały się „,́́rodkiem” do ucieczki od podatków, ale żeby też nieprzemyślane opodatkowanie nie skutkowało ucieczką od tej technologii i jej możliwego zastosowania. W polskim systemie podatkowym kwestie te zaczynają być dostrzegane i porządkowane, jakkolwiek niektóre państwa są już na znacznie dalszym etapie zaawansowania, przewidując nawet możliwość regulowania kryptowalutami zobowiązań podatkowych ${ }^{51}$. Nie mogąc zatem uniknąć tej problematyki, warto jak najlepiej i jak najwcześniej się do niej przygotować, co jednak wymaga jeszcze wielu zmian w przepisach podatkowych, tak aby zapewnić jednolite i spójne traktowanie kryptowalut w całym systemie podatkowym, odpowiadające istocie funkcji, którą pełnią i uwzgledniające specyfikę pozyskiwania i obrotu walutami wirtualnymi.

\section{BIBLIOGRAFIA}

Bala S., Kopyściański T., Srokosz W., 2016, Kryptowaluty jako elektroniczne instrumenty płatnicze bez emitowania. Aspekty informatyczne, ekonomiczne i prawne, Wydawnictwo Uniwersytetu Wrocławskiego, Wrocław.

Barta S., Murphy R., 2018 Zrozumieć Bitcoina: techniczny i ekonomiczny przewodnik po kryptowalutach, Fijorr Publishing, Wrocław (przekład Trąbski R.).

Boucher P., Nascimento S., Kritikos M., 2017, How blockchain technology could change our lives, Brussels, http://www.europarl.europa.eu/RegData/etudes/IDAN/2017/581948/EPRS_I DA(2017)581948_EN.pdf.

Company Taxation in the Internal Market, 2001, SEC 20011681.

Czarnocki J., 2017, Prawne aspekty zastosowania technologii blockchain na rynkach finansowych, [w:] W. Rogowski (red.), Regulacje finansowe. FinTech nowe instrumenty finansowe - resolution, C.H. Beck, Warszawa.

Dąbrowska J., 2017, Charakter prawny bitcoin, „Człowiek w Cyberprzestrzeni”, nr 1.

Distributed Ledger Technology: Beyond Block Chain, http://fintechpoland.com/wpcontent/uploads/2017/01/Technologie-rozproszonych-rejestrow-UK-GOfS-FTP-NASKPL.pdf.

Dudek P., 2016, Waluta bitcoin - glosa do wyroku Trybunału Sprawiedliwości z 22 października 2015 r. w sprawie C-264/14 Skatteverket przeciwko Davidowi Hedqvistowi, „Europejski Przegląd Sądowy”, nr 6.

${ }^{51}$ W Polsce kryptowaluty nie mogą być wykorzystane do spłaty zobowiązań podatkowych, podczas gdy w Szwajcarii kryptowalutą można opłacać podatki: Miasta Zug i Chiassow, w kantonie Ticino dopuszczają płatność podatków bitcoinami, jeśli podatek nie przekracza 250 franków szwajcarskich [www1]. 
Dyrektywa Parlamentu Europejskiego i Rady (UE) 2015/849 z 20 maja 2015 r. w sprawie zapobiegania wykorzystywaniu systemu finansowego do prania pieniędzy lub finansowania terroryzmu, zmieniająca rozporządzenie Parlamentu Europejskiego i Rady (UE) nr 648/2012 i uchylająca dyrektywę Parlamentu Europejskiego i Rady 2005/60/WE oraz dyrektywę Komisji 2006/70/WE (Dz.Urz. UE L 141 z 20 maja 2015 r., s. 73-117).

Dyrektywa Parlamentu Europejskiego i Rady (UE) 2018/843 z 30 maja 2018 r. zmieniająca dyrektywę (UE) 2015/849 w sprawie zapobiegania wykorzystywaniu systemu finansowego do prania pieniędzy lub finansowania terroryzmu oraz zmieniająca dyrektywy 2009/138/WE i 2013/36/UE (Dz.Urz. UE L 156 z 19 czerwca 2018 r., s. 43-74).

Dyrektywa Parlamentu Europejskiego i Rady 2009/110/WE z 1 września 2009 r. w sprawie podejmowania i prowadzenia działalności przez instytucje pieniądza elektronicznego oraz nadzoru ostrożnościowego nad ich działalnością, zmieniająca dyrektywy 2005/60/WE i 2006/48/WE oraz uchylająca dyrektywę 2000/46/WE (Dz.Urz. UE L 267 z 10 października 2009 r., s. 7-17).

Dyrektywa Parlamentu Europejskiego i Rady 2011/83/UE z 25 października 2011 r. w sprawie praw konsumentów, zmieniająca dyrektywę Rady 93/13/EWG i dyrektywę 1999/44/WE Parlamentu Europejskiego i Rady oraz uchylająca dyrektywę Rady 85/577/EWG i dyrektywę 97/7/WE Parlamentu Europejskiego i Rady (Dz.Urz. UE L 304 z 22 listopada 2011 r., s. 64 $-88)$.

Dyrektywa Rady 2006/112/WE z 28 listopada 2006 r. w sprawie wspólnego systemu podatku od wartości dodanej (Dz.Urz. UE L 347 z 11 grudnia 2006 r., s. 1-118).

European Central Bank, 2015, Virtual currency schemes - a further analysis, Frankfurt am Main, https://www.ecb.europa.eu/pub/pdf/other/virtualcurrencyschemesen.pdf.

European Commission, 2019, How can europe benefit from blockchain technologies?, Brussels, https://ec.europa.eu/digital-single-market/en/news/how-can-europe-benefit-blockchaintechnologies

Gomułowicz A., Małecki J., 2003, Ustawa o podatku dochodowym od osób fizycznych. Komentarz, „ABC”, Warszawa.

Gomułowicz A., Małecki J., 2013, Podatki i prawo podatkowe, LexisNexis Polska, Warszawa.

Hamaekers H., Holmes K., Głuchowski J., Kardach T., Nykiel W., 2006, Wprowadzenie do międzynarodowego prawa podatkowego, Wydawnictwo Prawnicze „LexisNexis”, Warszawa.

Homa D., 2015, Sekrety bitcoina i innych kryptowalut. Jak zmienić wirtualne pieniadze w realne zyski, Helion - Onepress, Gliwice.

Interpretacja Dyrektora Krajowej Informacji Skarbowej z 1 grudnia 2017 r. (0111-KDIB33.4012.122.2017.2.PK).

Interpretacja Dyrektora Izby Skarbowej w Katowicach z 21 czerwca 2013 r., (IBPP2/443258/13/ICz).

Interpretacja Dyrektora Izby Skarbowej w Katowicach z 29 lipca 2015 r. (IBPB-1-1/4511107/15/AB).

Interpretacja Dyrektora Izby Skarbowej w Łodzi z 18 lipca 2014 r. (IPTPB1/415-220/14-5/KSU i IPTPB1/415-221/14-10/KSU).

Interpretacja Dyrektora Izby Skarbowej w Poznaniu z 2 października 2014 r. (ILPB2/415-741/142/TR).

Interpretacja Dyrektora Izby Skarbowej w Poznaniu z 30 października 2014 r. (ILPB1/415746/14-4/AA).

Interpretacja Dyrektora Izby Skarbowej w Poznaniu z 6 kwietnia 2016 r. (ILPP5/4512-1-5/164/IP).

Interpretacja Dyrektora Izby Skarbowej w Poznaniu z 8 stycznia 2014 r. (ILPP1/443-910/132/AWa). 
Interpretacja Dyrektora Izby Skarbowej w Warszawie z 10 lipca 2014 r. (IPPB5/423-397/144/MW).

Interpretacja Dyrektora Izby Skarbowej w Warszawie z 25 lutego 2014 r. (IPPB2/415-842/132/MK).

Interpretacja Dyrektora Izby Skarbowej w Warszawie z 26 czerwca 2014 r. (IPPB1/415-276/144/EC).

Interpretacja Dyrektora Krajowej Informacji Skarbowej z 19 października 2018 r. (0112-KDIL31.4011.350.2018.1.AN).

Interpretacja Dyrektora Krajowej Informacji Skarbowej z 24 października 2018 r. (0111-KDIB22.4014.99.2018.6.MZ).

Interpretacja Dyrektora Krajowej Informacji Skarbowej z 2 marca 2019 r. (0113KDIPT3.4011.599.2018.1.SK).

Interpretacja Dyrektora Krajowej Informacji Skarbowej z 22 grudnia 2017 r. (0113-KDIPT21.4011.472. 2017.1.DJD).

Interpretacja Dyrektora Krajowej Informacji Skarbowej z 3 kwietnia 2017 r. (2461-IBPB-22.4511.12.2017.2.BF).

Interpretacja Dyrektora Krajowej Informacji Skarbowej z 30 listopada 2017 r. (0111KDIB4.4014.393.2017.3.PM).

Interpretacja Dyrektora Krajowej Informacji Skarbowej z 30 maja 2019 r. (0114-KDIP22.4010.69.2019.4.AG).

Interpretacja Dyrektora Krajowej Informacji Skarbowej z 8 maja 2019 r. (0113-KDIPT23.4011.100.2019.2.PRz).

Iwanicz-Drozdowska M., Matuszyk A., Nowak A., Kitala R., 2009, Produkty finansowe i edukacja finansowa $w$ Polsce na tle wybranych krajów wysokorozwiniętych. Raport z badań, Szkoła Główna Handlowa w Warszawie, Warszawa.

Kiszka J., 2003, Ochrona podatnika w prawie Unii Europejskiej, „Przegląd Podatkowy”, nr 8.

Klinger A., Szczepański J., 2017, Blockchain - historia, cechy i główne obszary zastosowań, „Człowiek w cyberprzestrzeni”, $\mathrm{nr} 1$.

Komisja Europejska - Komunikat prasowy, 2018, Komisja uruchamia Unijne Obserwatorium i Forum ds. Lańcucha Bloków, Bruksela, http://europa.eu/rapid/press-release_IP-18521_pl.htm.

Komunikat Ministerstwa Finansów z 4 kwietnia 2018 r. Skutki podatkowe obrotu kryptowalutami w PIT, VAT i PCC, www.mf.gov.pl.

Kopańko K., Kozłowski M., 2015, Bitcoin. Złoto XXI wieku, Helion - Onepress, Gliwice.

Kotowska E., 1998, Dostosowanie polskiego prawa do wymogów Unii Europejskiej, „Zeszyty Naukowe", nr 11.

Modzelewski W. (red.), 2008, Wstęp do nauki polskiego prawa podatkowego, Instytut Studiów Podatkowych Modzelewski i Wspólnicy, Warszawa.

Nakamoto S., 2008, Bitcoin: A Peer-to-Peer Electronic Cash System, https://nakamotoinstitute.org/bitcoin/

Ofiarski Z., 2017, Prawo bankowe: komentarz, LEX a Wolters Kluwer business, Warszawa.

Opinia Rzecznika Generalnego Juliane Kokott z 16 lipca 2015 r. Sprawa C-264/14 Skatteverket przeciwko Davidowi Hedqvistowi.

Piech K. (red.), 2016, Leksykon pojęć na temat technologii blockchain $i$ kryptowalut, https://www.gov.pl/documents/31305/0/leksykon_pojec_na_temat_technologii_blockchain_i _kryptowalut.pdf/77392774-1180-79ab-4dd5-089ffab37602.

Prokurat J., 2015, Podatkowe aspekty obrotu wirtualnymi walutami, „Przegląd Podatkowy”, nr 3.

Rezolucja Parlamentu Europejskiego 17 maja 2017 r. w sprawie FinTech: wpływ technologii na przyszłość sektora finansowego (2016/2243(INI). 
Rezolucja Parlamentu Europejskiego z 26 maja 2016 r. w sprawie wirtualnych walut (2016/2007(INI).

Rezolucja Parlamentu Europejskiego z 3 października 2018 r. w sprawie technologii rozproszonego rejestru i łańcuchów bloków: budowanie zaufania do przepływów funduszy z pominięciem pośrednictwa bankowego (2017/2772(RSP).

Romanowski M., 2006, Podziat praw podmiotowych na majątkowe i niemajątkowe, „Państwo i Prawo", nr 3.

Rozporządzenie Ministra Finansów z 18 grudnia 2019 r. zmieniające rozporządzenie w sprawie zaniechania poboru podatku od czynności cywilnoprawnych od umowy sprzedaży lub zamiany waluty wirtualnej (Dz. U. 2019, poz. 2459).

Rozporządzenie Ministra Finansów z 11 lipca 2018 r. w sprawie zaniechania poboru podatku od czynności cywilnoprawnych od umowy sprzedaży lub zamiany waluty wirtualnej (Dz.U. 2018, poz. 1346 ze zm.).

Rozporządzenie Ministra Finansów z 24 czerwca 2019 r. zmieniające rozporządzenie w sprawie zaniechania poboru podatku od czynności cywilnoprawnych od umowy sprzedaży lub zamiany waluty wirtualnej (Dz. U. 2019, poz. 1184).

Stolarski K., 2018, Prawny i podatkowy status walut wirtualnych $w$ kontekście wprowadzenia do prawa polskiego definicji legalnej waluty wirtualnej, „Monitor Podatkowy”, $\mathrm{nr} 9$.

Szostek D., 2018, Blockchain a prawo, C.H. Beck, Warszawa.

The Law Library of Congress, Global Legal Research Center, 2014, Regulation of Bitcoin in Selected Jurisdictions, Washington.

Ustawa z 19 sierpnia 2011 r. o usługach płatniczych (tekst jedn., Dz.U. 2019, poz. 659 ze zm.).

Ustawa z 1 marca 2018 r. o przeciwdziałaniu praniu pieniędzy oraz finansowaniu terroryzmu (tekst jedn., Dz.U. 2019, poz. 1115 ze zm.).

Ustawa z 11 marca 2004 r. o podatku od towarów i usług (tekst jedn., Dz.U. 2018, poz. 2174 ze zm.).

Ustawa z 15 lutego 1992 r. o podatku dochodowym od osób prawnych (tekst jedn., Dz.U. 2019, poz. $865 \mathrm{ze} \mathrm{zm}$.).

Ustawa z 23 kwietnia 1964 r. - Kodeks cywilny (tekst jedn., Dz.U. 2019, poz. 1145 ze zm.).

Ustawa z 23 października 2018 r. o zmianie ustawy o podatku dochodowym od osób fizycznych, ustawy o podatku dochodowym od osób prawnych, ustawy - Ordynacja podatkowa oraz niektórych innych ustaw (Dz.U. 2018, poz. 2193).

Ustawa z 26 lipca 1991 r. o podatku dochodowym od osób fizycznych (tekst jedn., Dz.U. 2019, poz. $1387 \mathrm{ze} \mathrm{zm}$.).

Ustawa z 28 lipca 1983 r. o podatku od spadków i darowizn (tekst jedn., Dz.U. 2019, poz. 1813).

Ustawa z 29 lipca 2005 r. o obrocie instrumentami finansowymi (tekst jedn., Dz.U. 2018, poz. $2286 \mathrm{ze} \mathrm{zm}$.).

Ustawa z 29 sierpnia 1997 r. - Prawo bankowe (tekst jedn., Dz.U. 2019, poz. 2357).

Ustawa z 30 maja 2014 r. o prawach konsumenta (tekst jedn., Dz.U. 2019, poz. 134 ze zm.).

Ustawa z 9 września 2000 r. o podatku od czynności cywilnoprawnych (tekst jedn., Dz.U. 2019, poz. 1519 ze zm.).

Wolter A., Ignatowicz J., Stefaniuk K., 2018, Prawo cywilne. Zarys części ogólnej, Wolters Kluwer Polska, Warszawa.

Wyrok NSA z 6 marca 2018 r. (II FSK 488/16).

Wyrok TSUE z 14 lipca 1998 r. w sprawie C-172/96 Commissioners of Customs \& Excise przeciwko First National Bank of Chicago.

Wyrok TSUE z 22 października 2015 roku w sprawie C-264/14 Skatteverket przeciwko Davidowi Hedqvistowi.

Wyrok WSA w Łodzi z 23 marca 2016 r. (I SA/Łd 54/16).

Wyrok WSA w Olsztynie z 9 maja 2018 r. (I SA/Ol 202/18). 
Wyrok WSA w Warszawie z 11 września 2015 r. (III SA/Wa 3374/14).

[www1] http://fortune.com/2017/09/12/switzerland-chiasso-bitcoin-tax-zug/

[www2] http://ict-infcomtech.lu/index.php/2015/08/10/view-on-regulation-for-bitcoin-in-thegrand-duchy/

[www3] https://bezprawnik.pl/kryptowaluty-pcc-podatek/

[www4] https://businessinsider.com.pl/technologie/blockchain/powstaje-unijne-forum-dsblockchaina/et3398d

[www5] https://news.bitcoin.com/use-bitcoin-ecuador-grow-government-ban/

[www6] https://www.gov.pl/web/cyfryzacja/od-papierowej-do-cyfrowej-polski

[www7] https://www.spidersweb.pl/2018/04/chaos-w-rozliczeniach-podatkowych-zkryptowalut.html

Zacharzewski K., 2015, Praktyczne znaczenie bitcoina na wybranych obszarach prawa prywatnego, „Monitor Prawniczy”, nr 4.

Zalcewicz A., Bajor B., 2016, Ustawa o ustugach platniczych. Komentarz, Wolters Kluwer, Warszawa.

\title{
FINANCIAL SERVICES AND BLOCKCHAIN TECHNOLOGY - CURRENT TAX PROBLEMS AND CHALLENGES
}

\begin{abstract}
Financial services due to the possibility of using virtual currencies (mainly bitcoins) for payments based on blockchain technology take on a new dimension. Making direct payments with the use of cryptocurrencies creates numerous tax-related issues, both in terms of acquiring and trading in virtual currencies, including in particular using them to perform the payment function, but also treating them as an investment or commercial activity. The issues related to this generate numerous tax challenges, both in the income tax system, as well as in turnover and property tax systems. These challenges, resulting from the need to determine the tax consequences of the use of blockchain technology in the financial services system for payments with cryptocurrencies, this paper has been devoted to.
\end{abstract}

Keywords: financial services, blockchain, virtual currencies, crypto-currencies, taxes. 